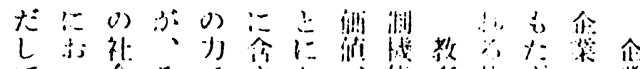

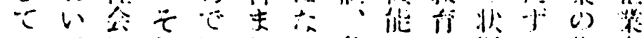

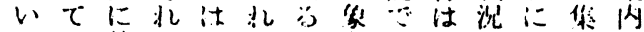

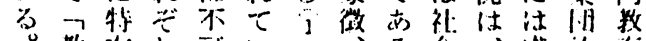

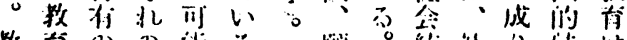

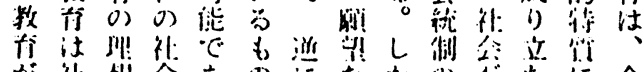

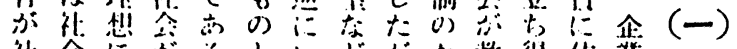

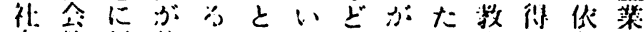

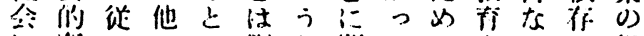

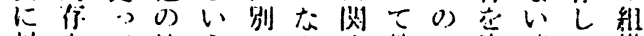

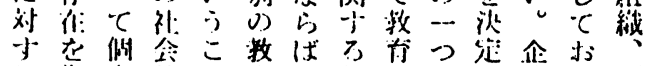

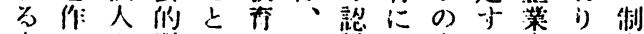

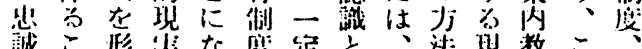

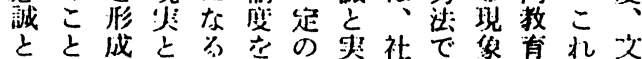

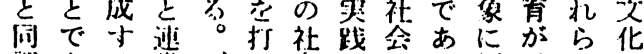

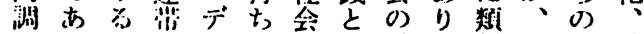

心 う洲性二这でが隽、似企特技

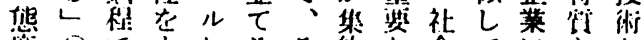

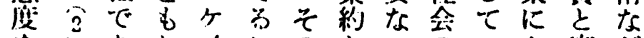

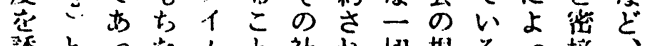

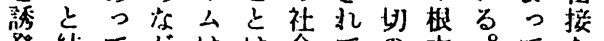

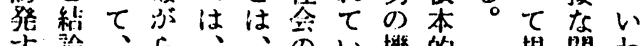

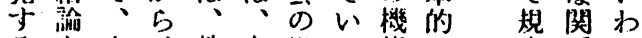

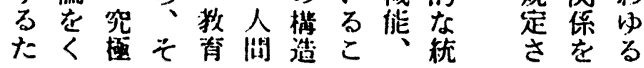

企
業
教
充
の
あ
方
に
方
て
て

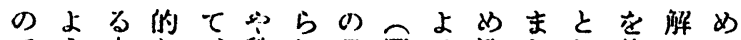

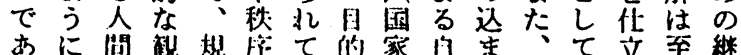

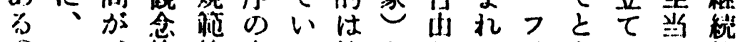

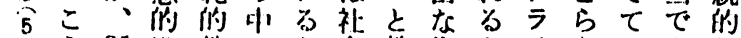

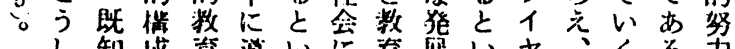

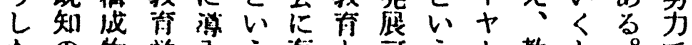

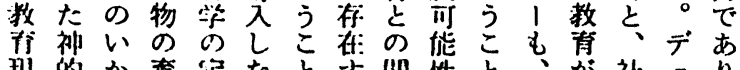

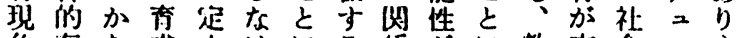

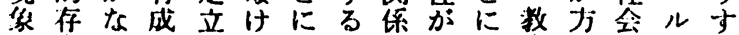

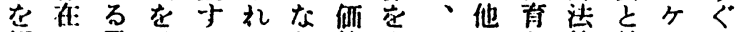

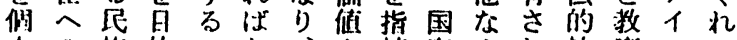

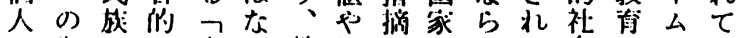

加附にと人ら划礼しになる会とは社

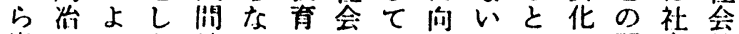

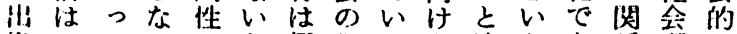

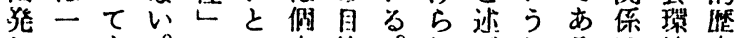

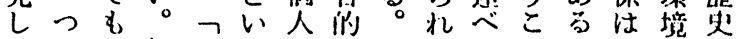

たのま规部うをに合る、とこ分が们

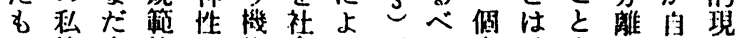

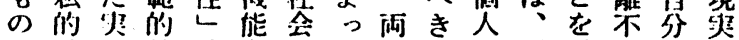

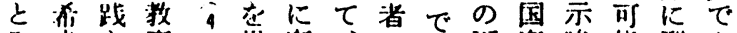

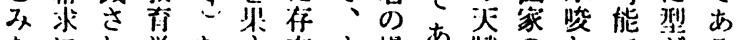

なに机学な与在す場あ珷のしでどる

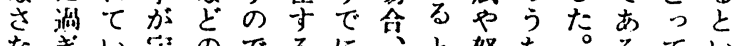

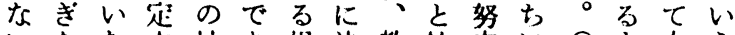

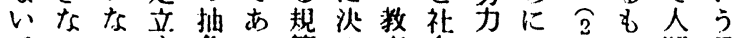

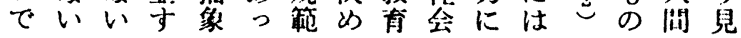




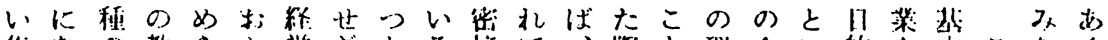

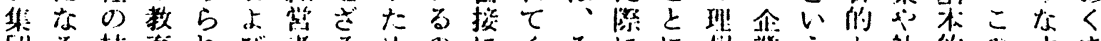

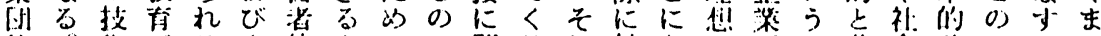

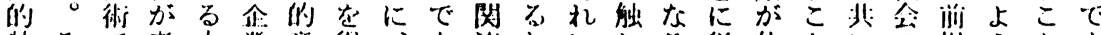

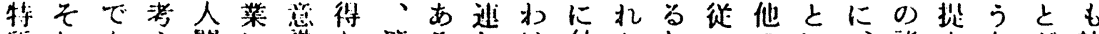

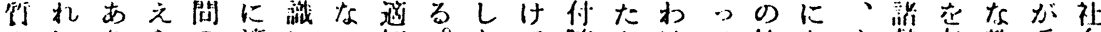

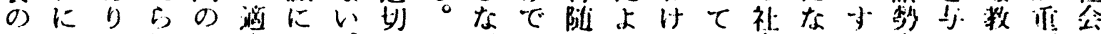

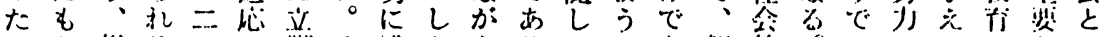

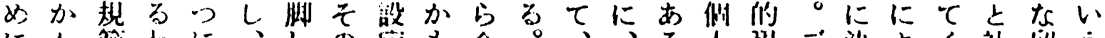

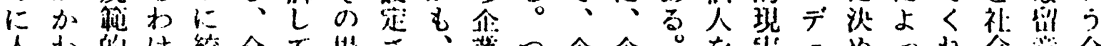

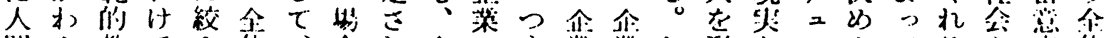

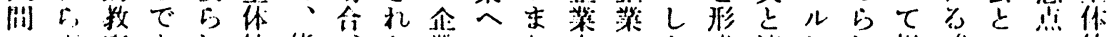

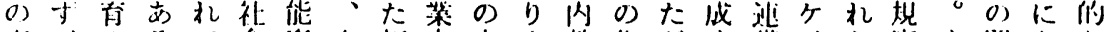

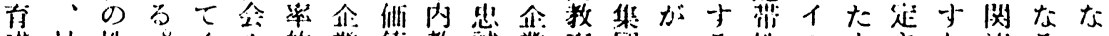

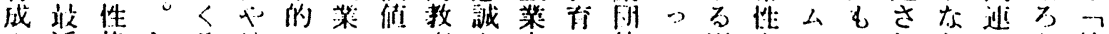

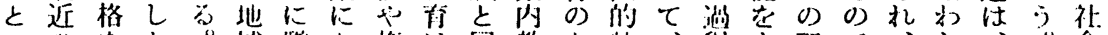

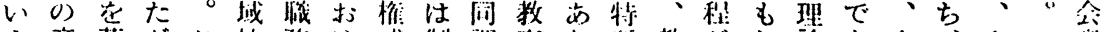

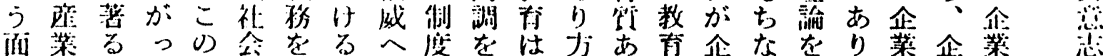

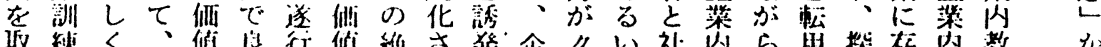

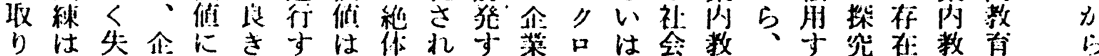

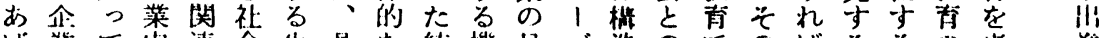

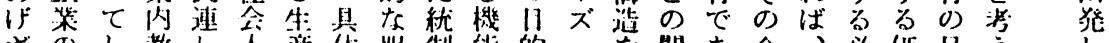

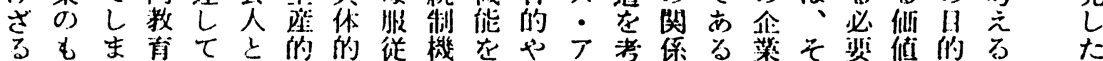

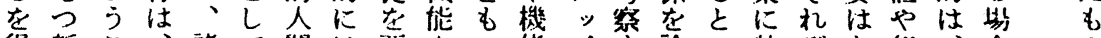

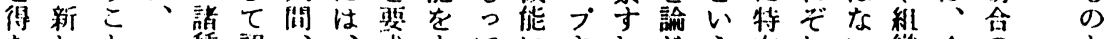

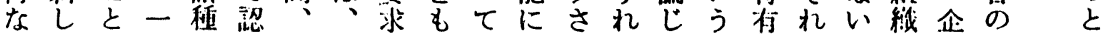

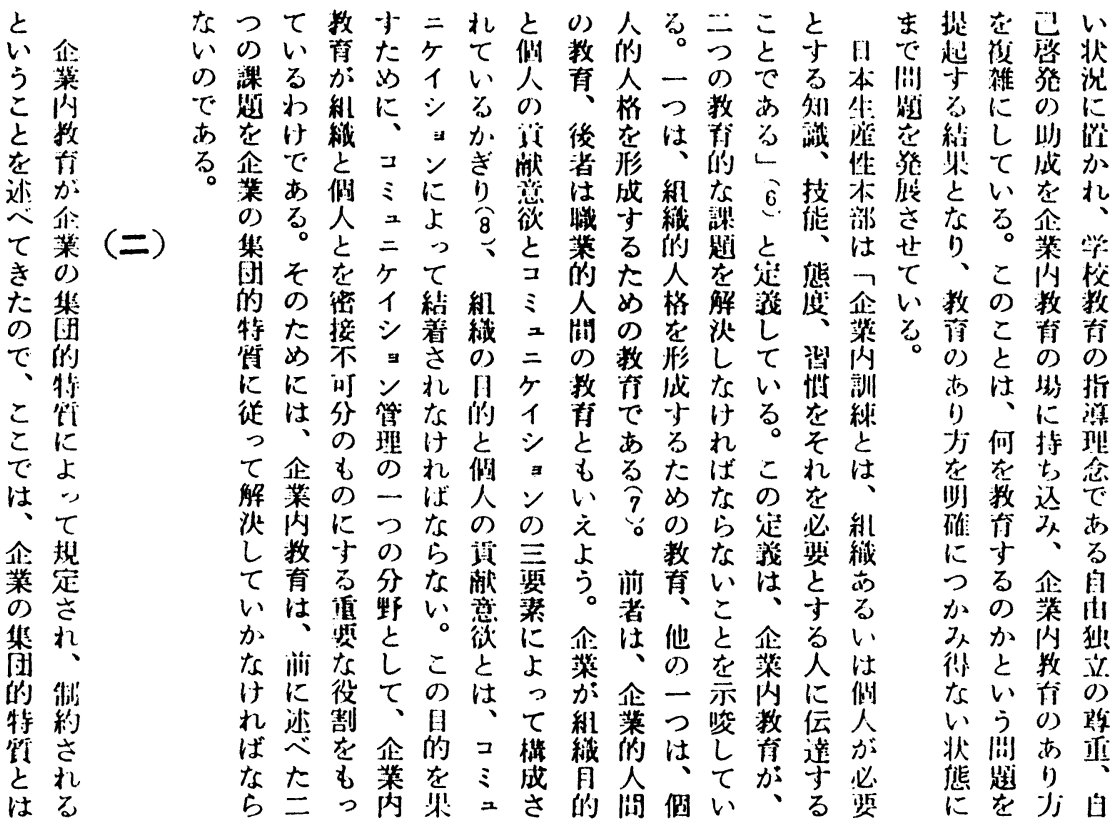




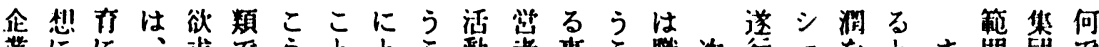

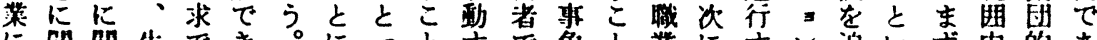
に明间生でき。にっとすで象と業にすン追いず内的あ

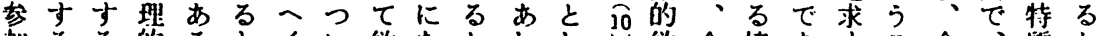

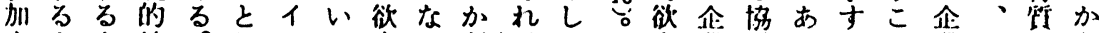

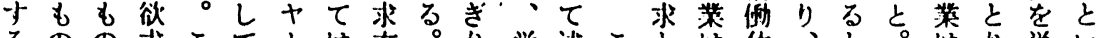

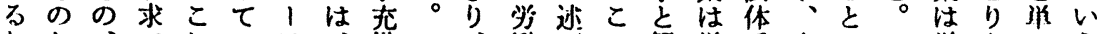

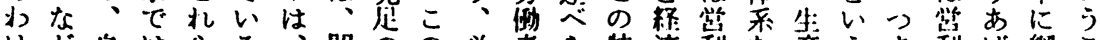
けと白はらる、间のの必者ら特済利な産うま利げ䋚こ でが我金の。人题たよ然で机到们集の的程りをて羅と

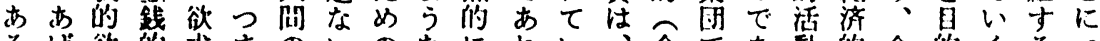
るげ欲的求まのいのなに机い、金であ動们企的くるつ から求報のり欲と努意自:る通銭ある者業とこのい

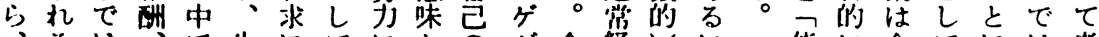

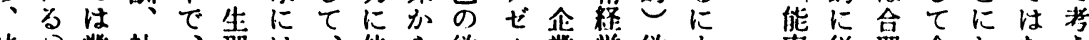

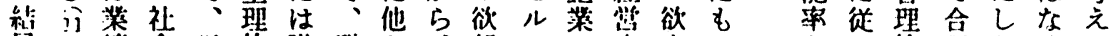

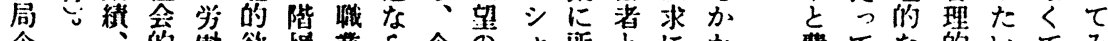

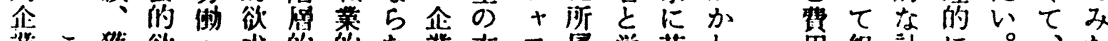

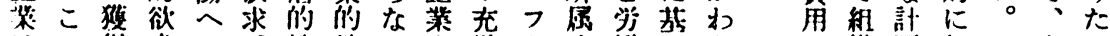

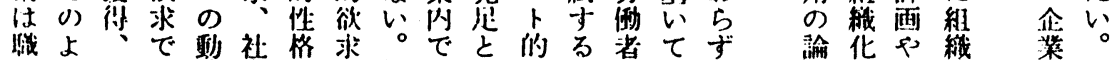

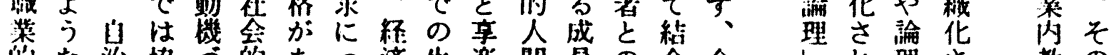

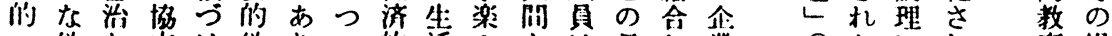

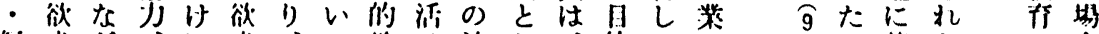

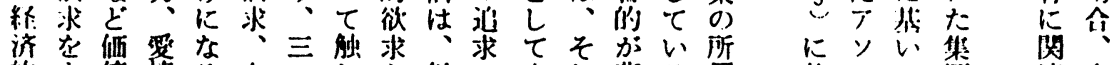

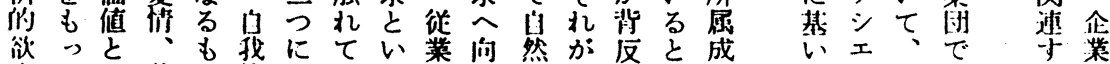

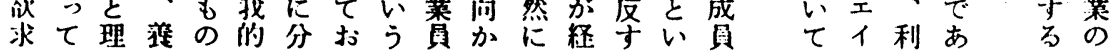

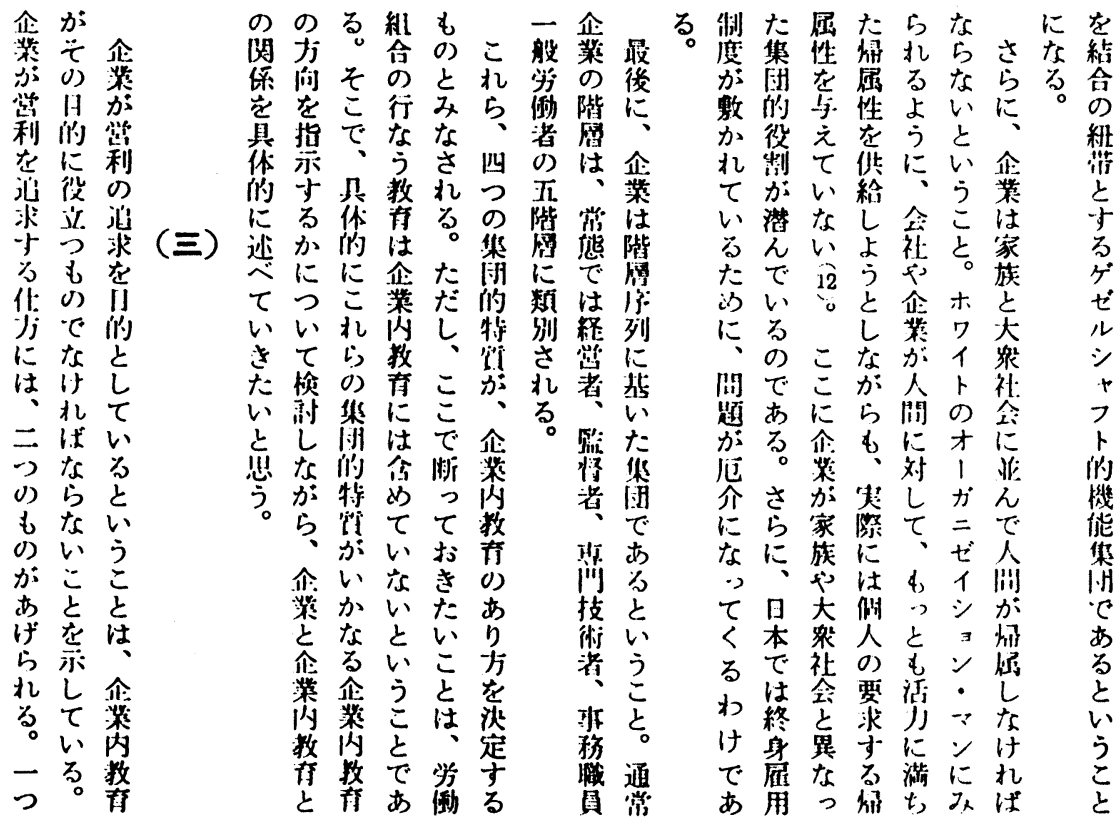




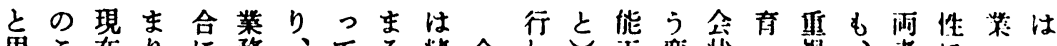

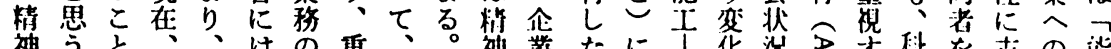

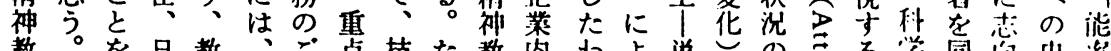

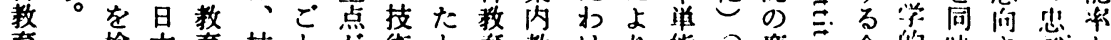

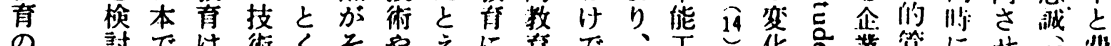

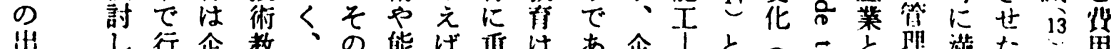

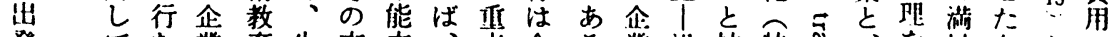

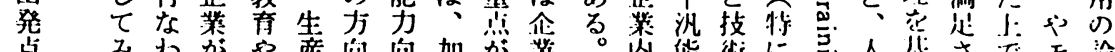

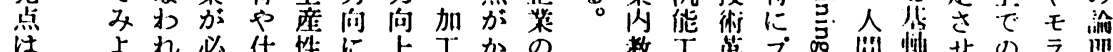

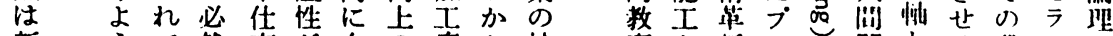
新う。然事方向の虐か技 入。的の樋け矵菜る術 社まるに訓接ら練や少们 員ず教行練個れよ装、組

の、育なに人るり厝仕: 織

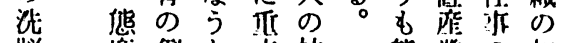

嗵度例之点技一热業の如

教やをい苾術方度で訓何

章精見うおや中やは練に

に神なこか能小精、に上

始教が机力企种裴近

ま 青らでるに業の㑣焦て

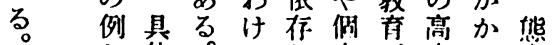

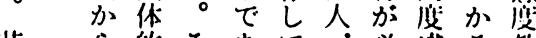

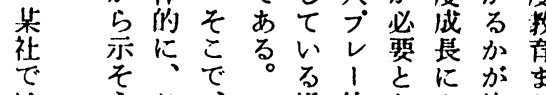

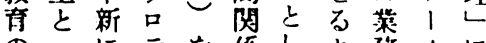

のいにテを倸し占稀儿に

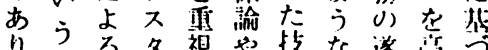

りう方視や技な遂棌势

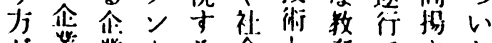

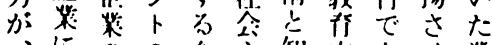

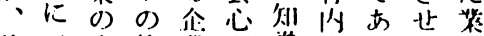
仕必变倫業理娍行ええ矽 拃要化理と学の老。

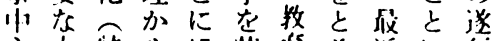

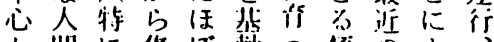

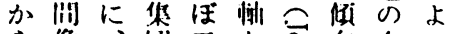

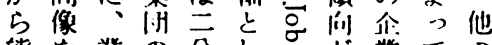

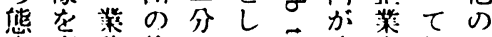

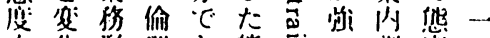

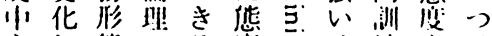

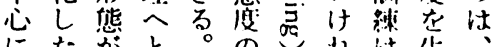

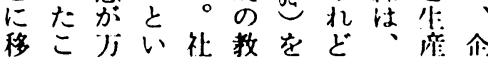

はうこ、っ塨的なよ決た

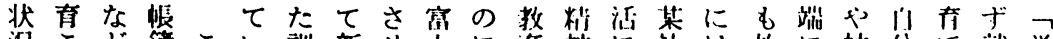

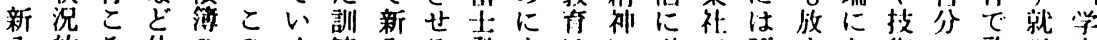

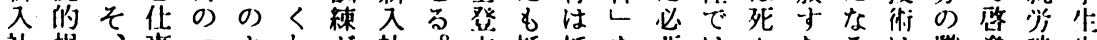

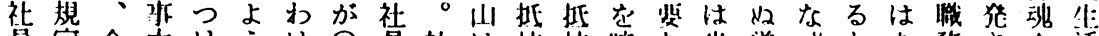

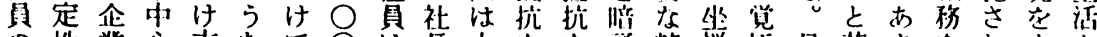

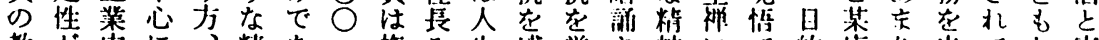

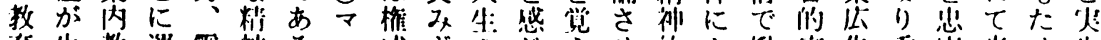

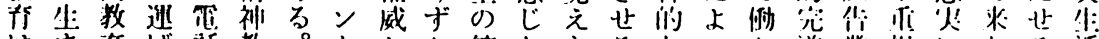

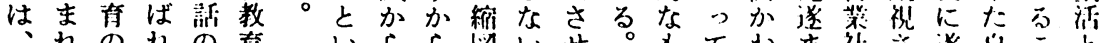

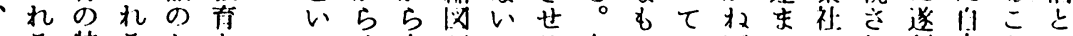

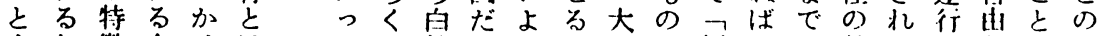

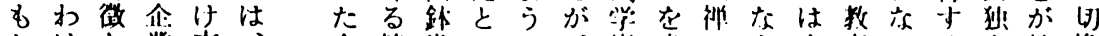

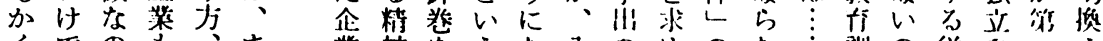

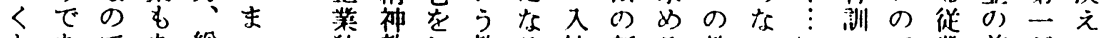

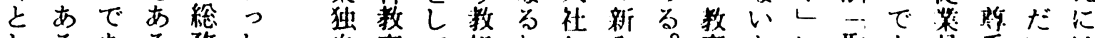

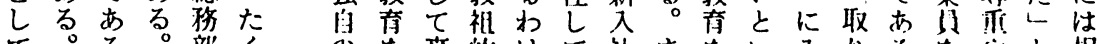

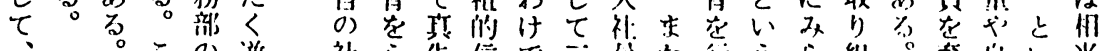

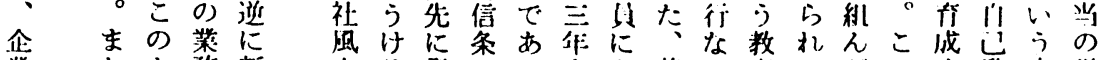

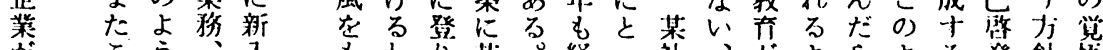

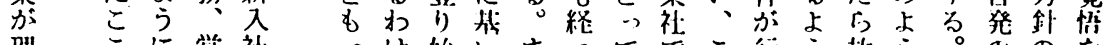

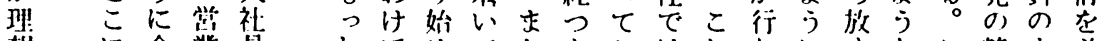

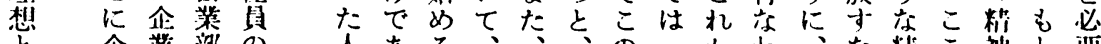

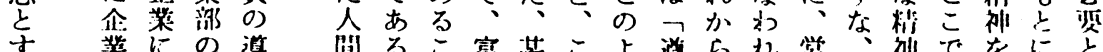

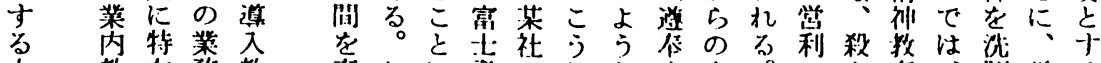

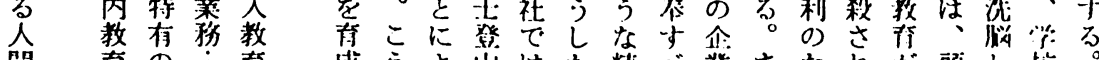

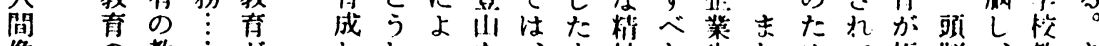

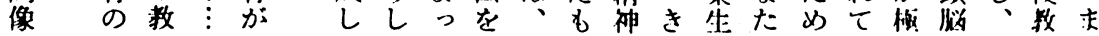




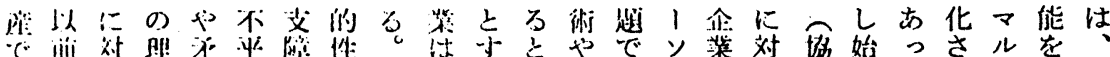

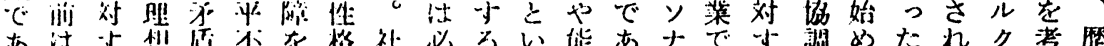

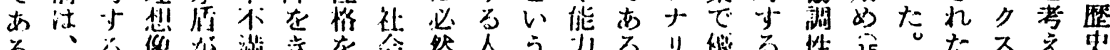

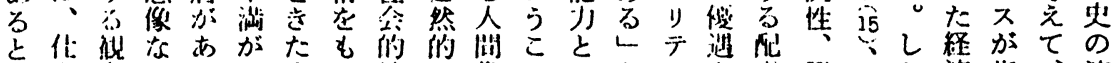

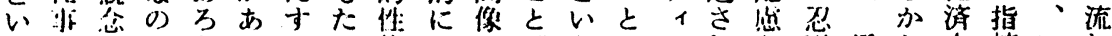

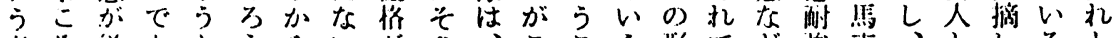

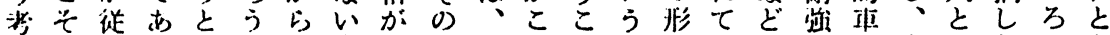

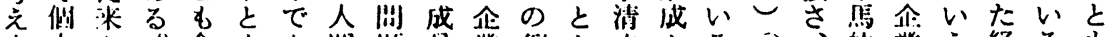

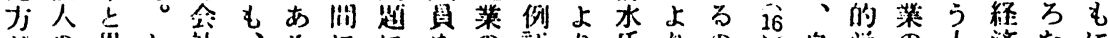

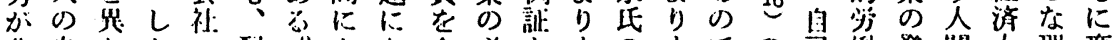

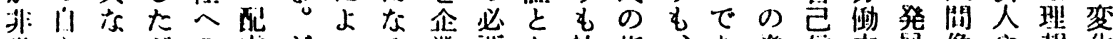

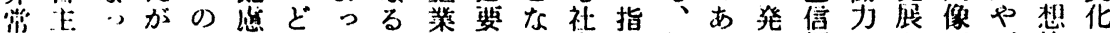

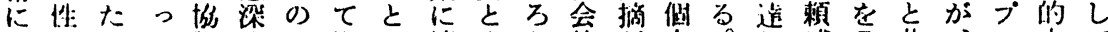

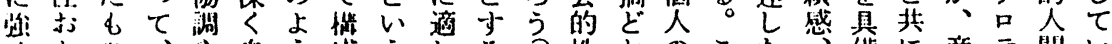

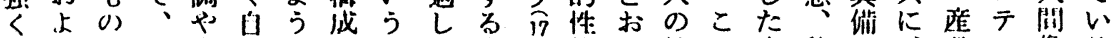

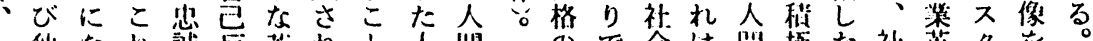

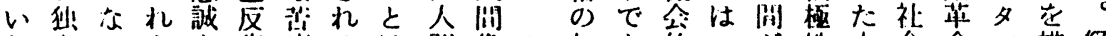

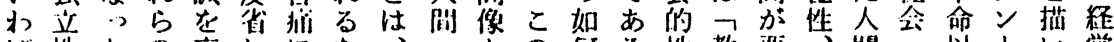

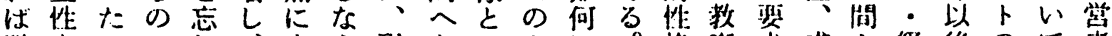

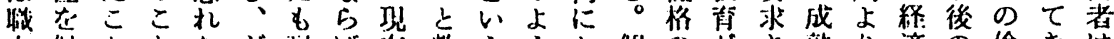

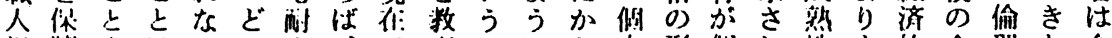

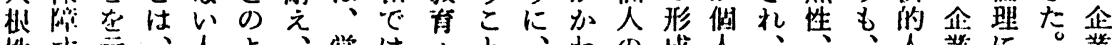

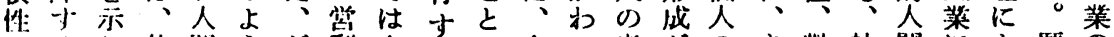

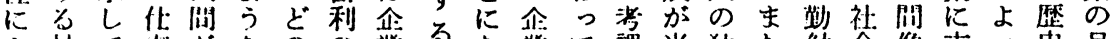

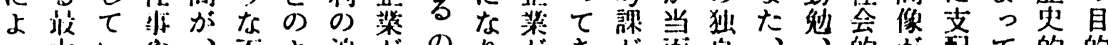

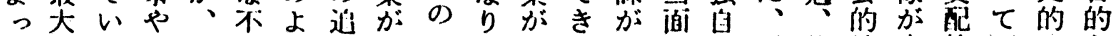

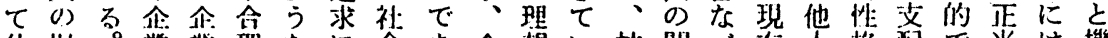

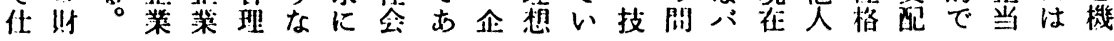

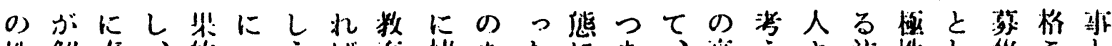

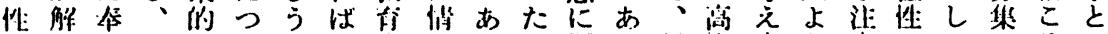

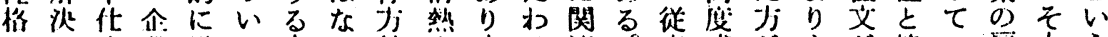

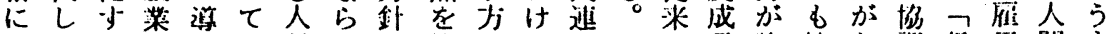

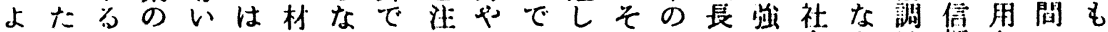

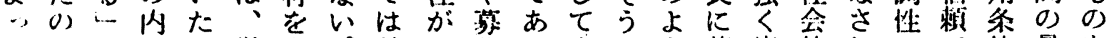

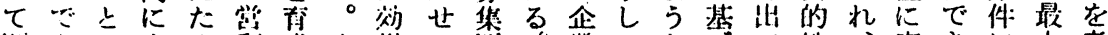

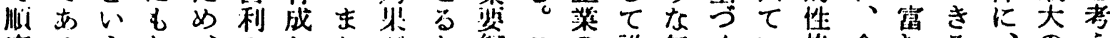
太るうち、のしたがた納この誰年くい格企主るすのえ

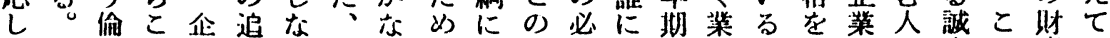

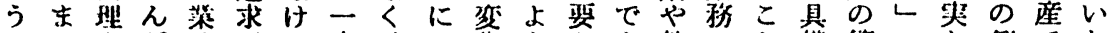

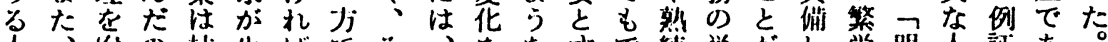

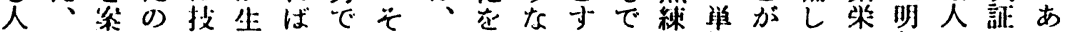

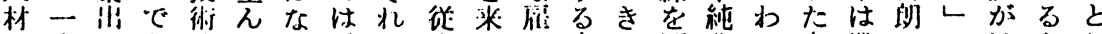

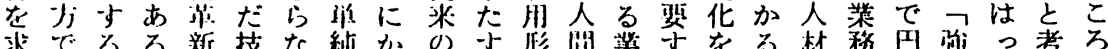
冰でるる。新技な維か心

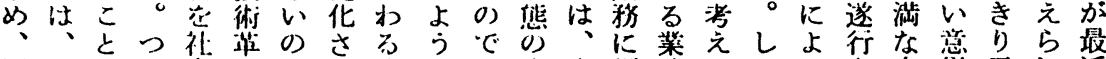

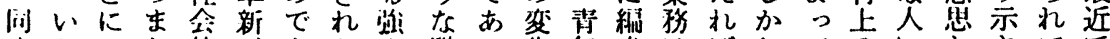

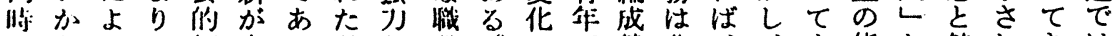

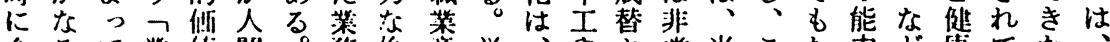

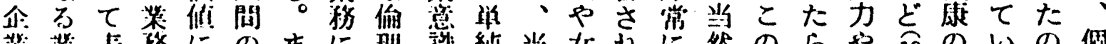

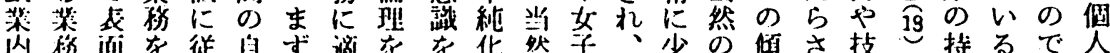

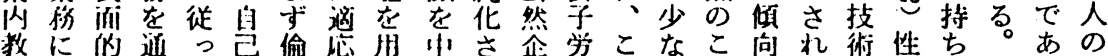

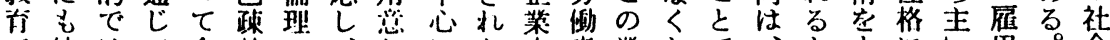

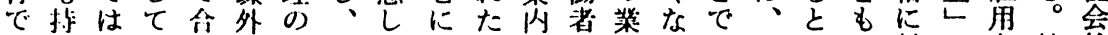

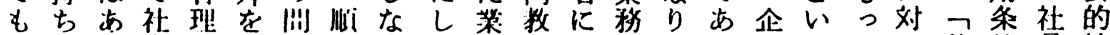

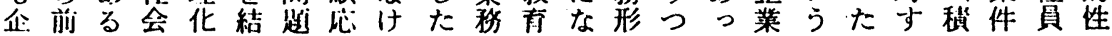




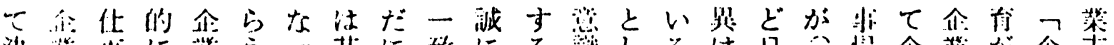

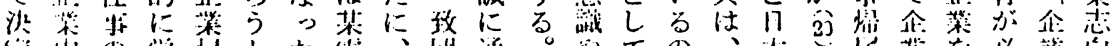

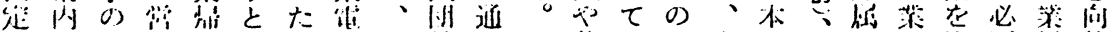

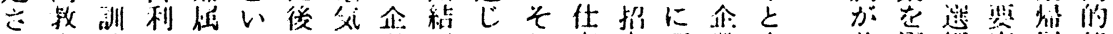

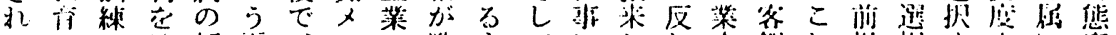

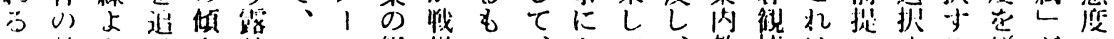

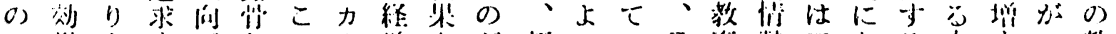

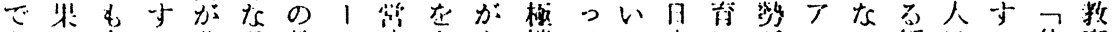

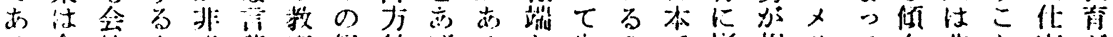

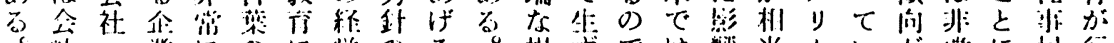

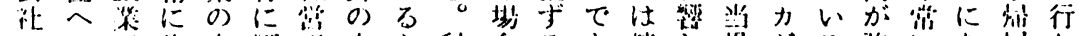

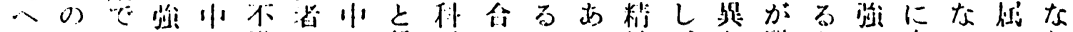

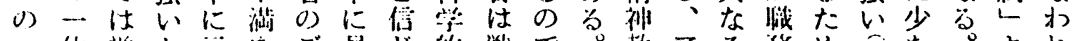

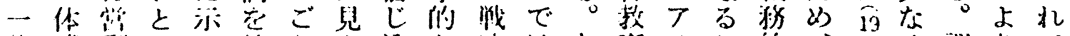

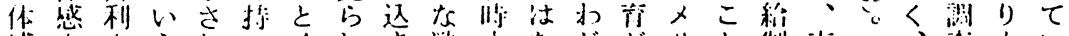

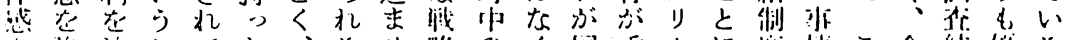

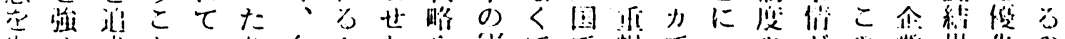

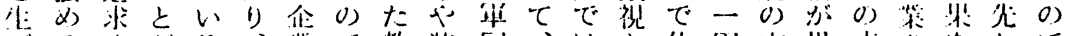

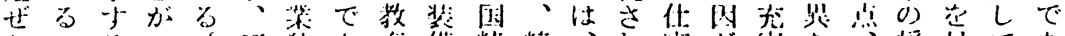

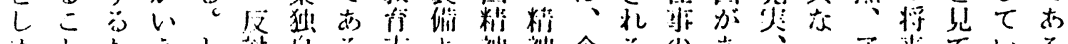

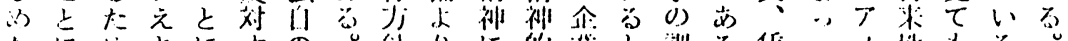

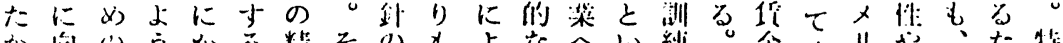

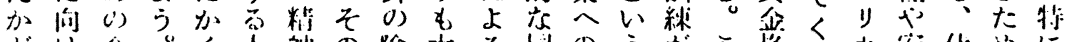

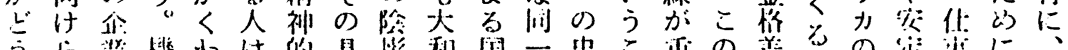
引

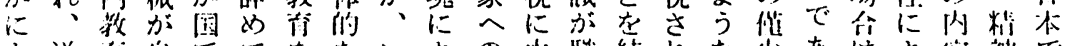

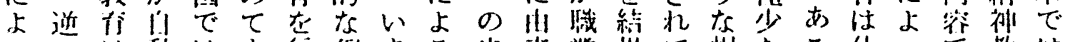

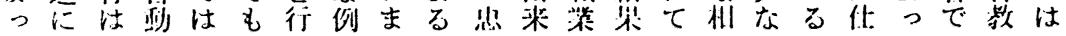

系 $上-5$

に间市。

戈: 速桨

いLいO

$\tau \tau j 11$

維: 2 讪

持企とに

さ策法燳

机芮、係

七敃企等

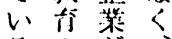

る心 方

上あ具成

(b) 低

$j y_{j}$ 的

侎芯に娍

䩼港桜

o) 好伐们

样る欲

留。に求

们企よ $\frac{1}{2}$

特藉つ粒

们茫游

住人機似

湖汭优微

人日 0 占冰

老四了当在

乙 聊こ通

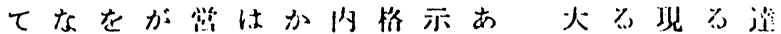

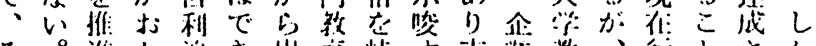

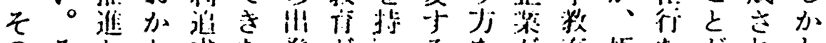

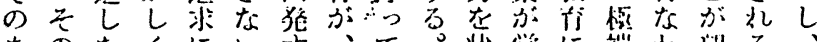

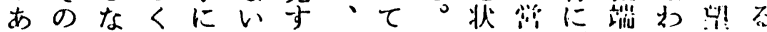

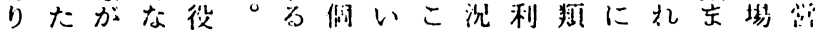

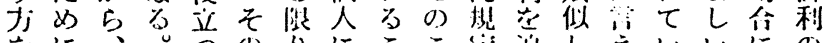

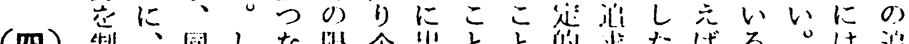

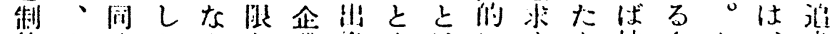

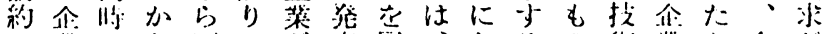

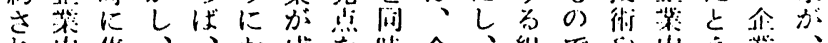

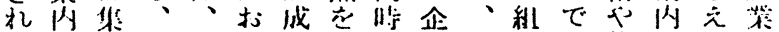

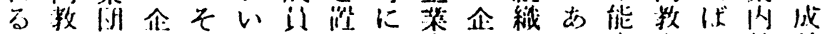

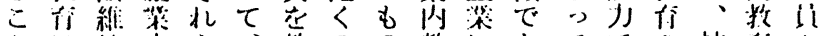

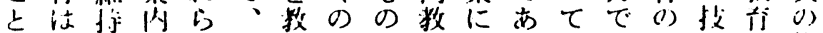

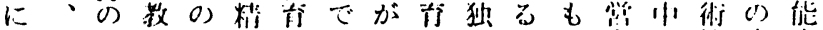

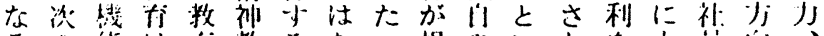

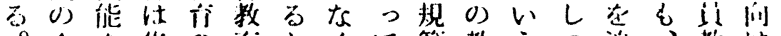

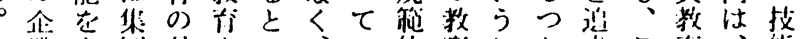

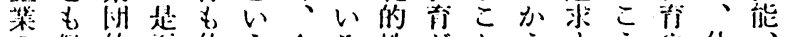

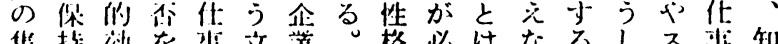

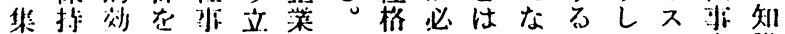

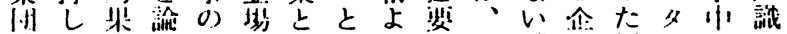

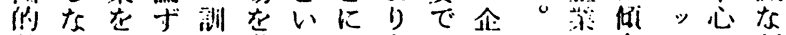

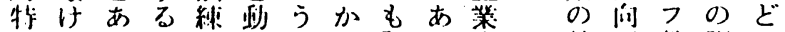

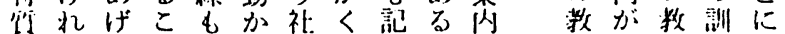

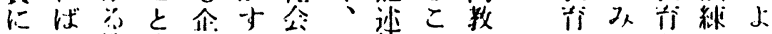

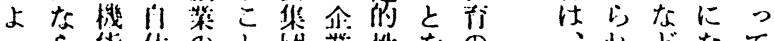




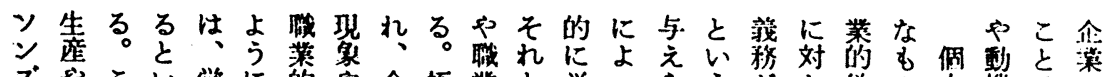

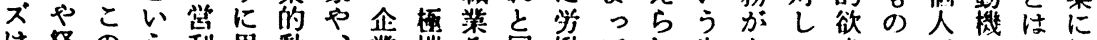

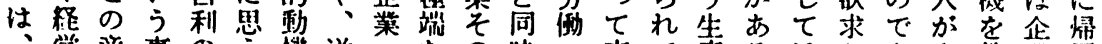

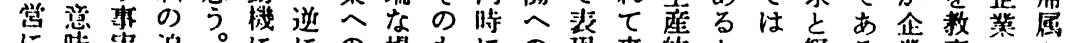

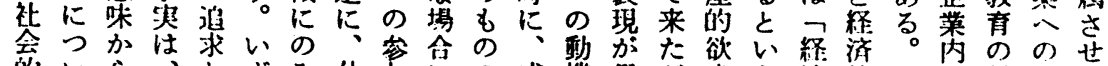

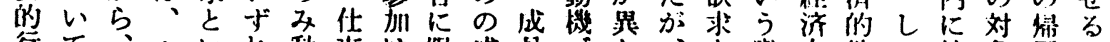

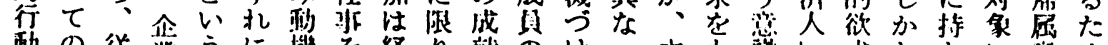

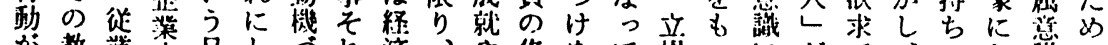

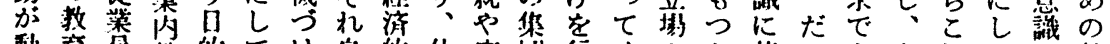

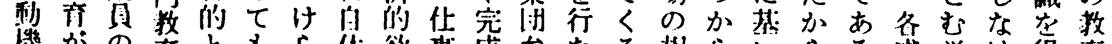

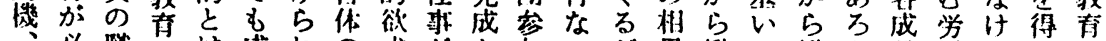

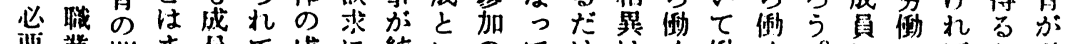

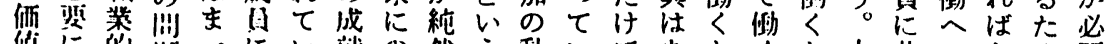

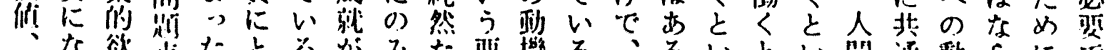

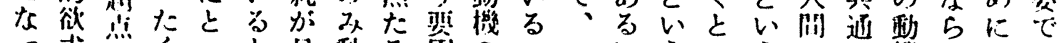

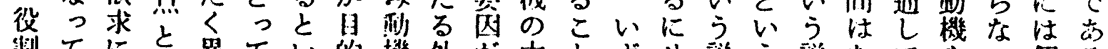

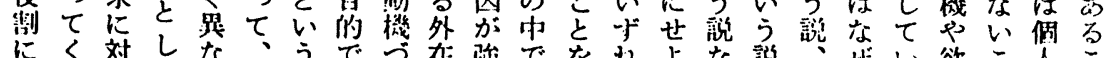

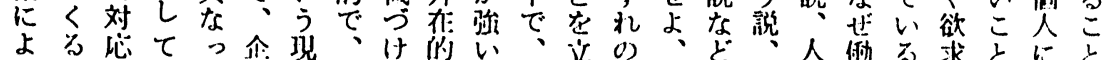

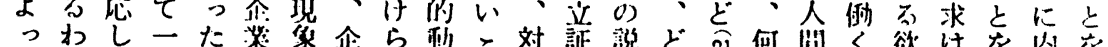

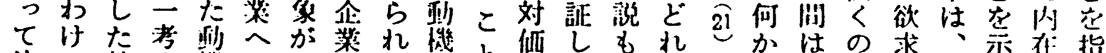

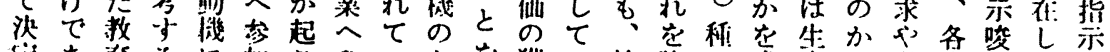

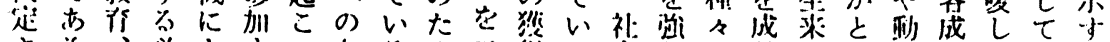

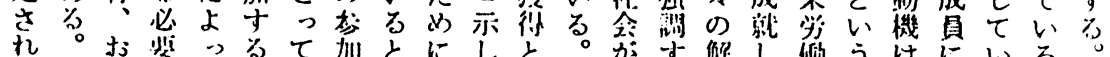

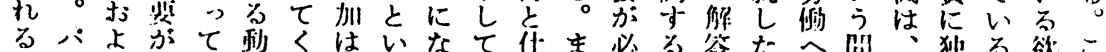

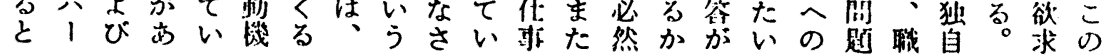

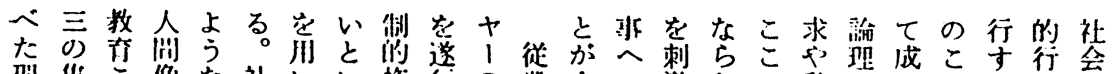

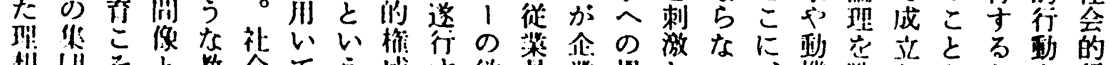

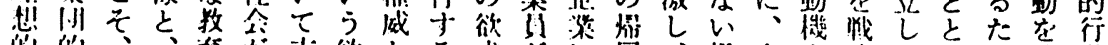

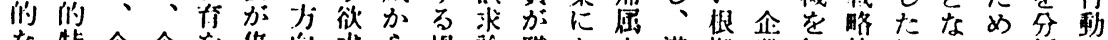

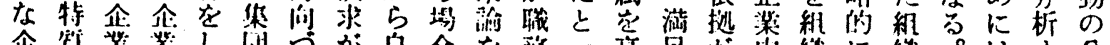

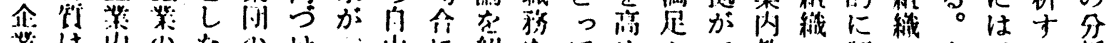

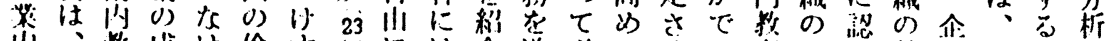

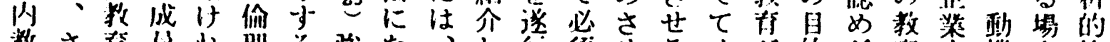

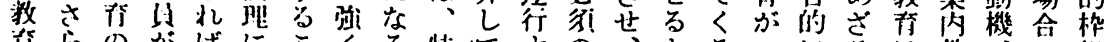

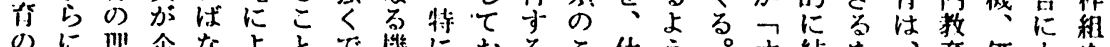

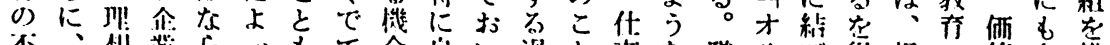

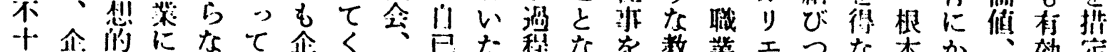

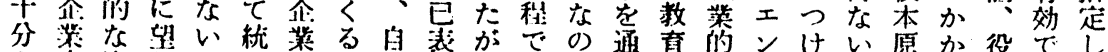

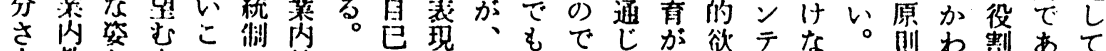

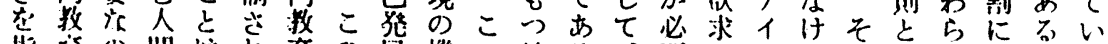

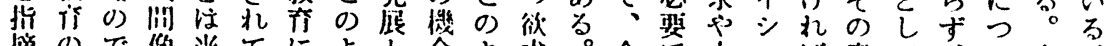

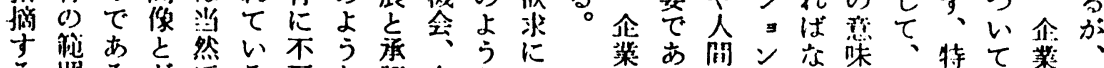

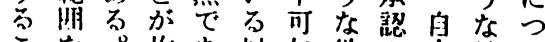

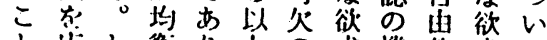

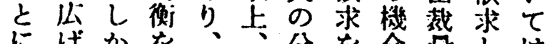
にげかを、分を会而とは

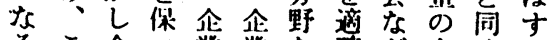

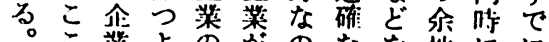
こ蔡よの占のな地にに でのう望こで手得業へ 边第な它のあ段た市邪イ

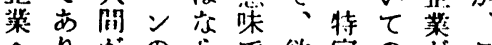
人りがのらで欲定のがこ の、扸教な教求の企目行

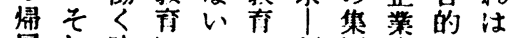

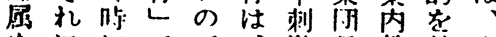
をににでで、湤月教効企 离よ持なお僻门的青製業 めつつける人反にが的の るて動机。の応上必生 こ仕機ば欲のっ顶遂滻 


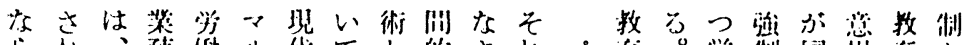

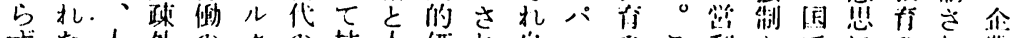

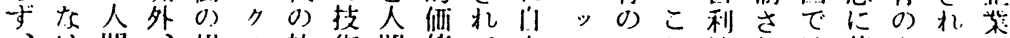

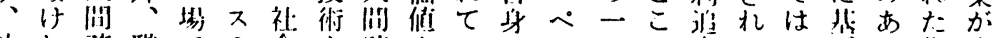

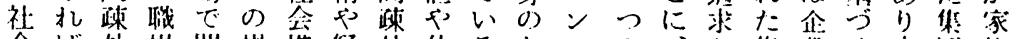

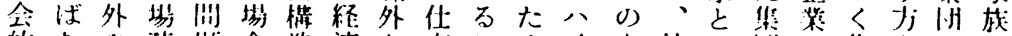

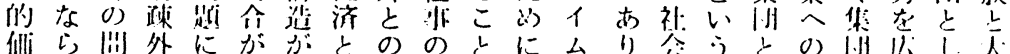

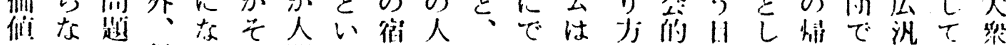
o) W

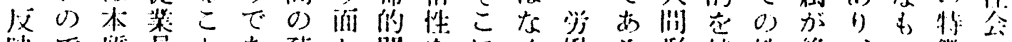

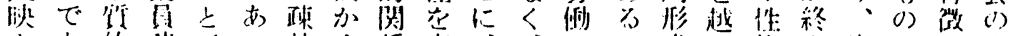

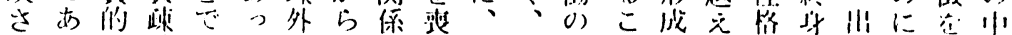

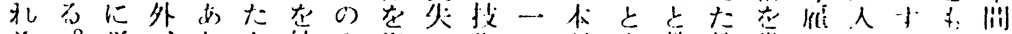

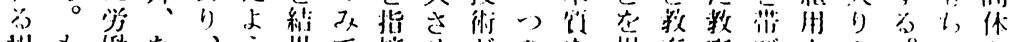

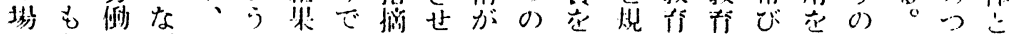

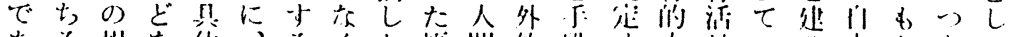

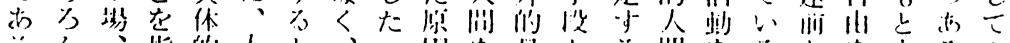

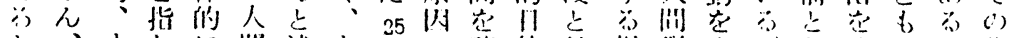

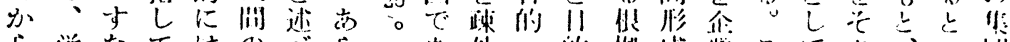

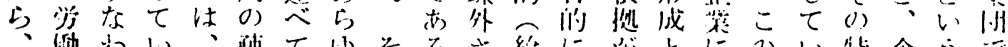

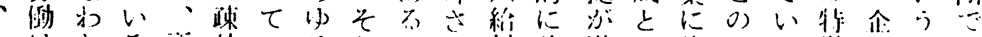

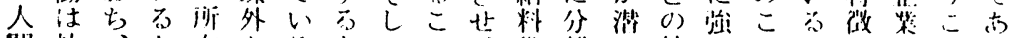

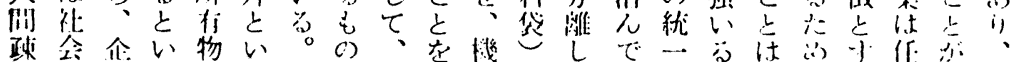

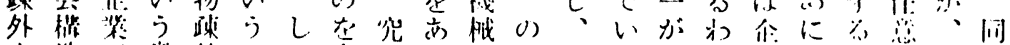

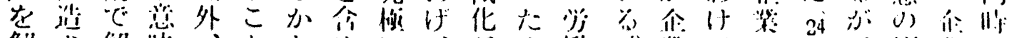

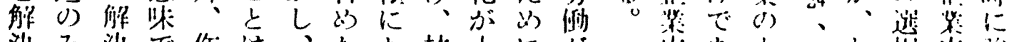

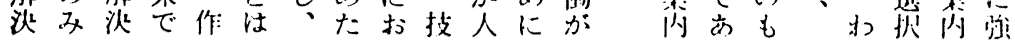

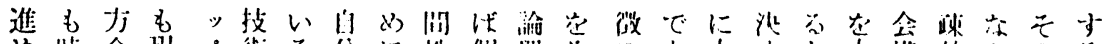

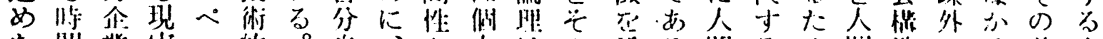

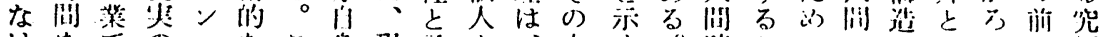

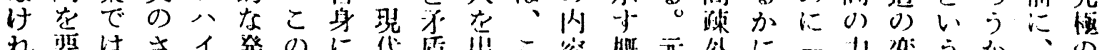

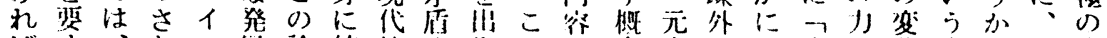

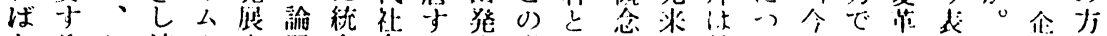

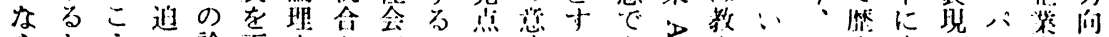

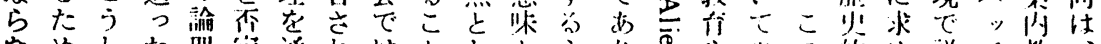

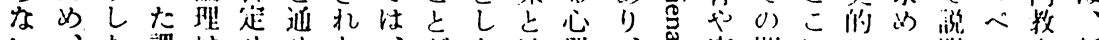

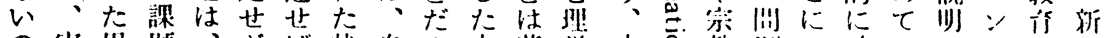

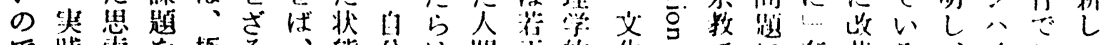

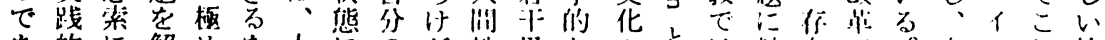

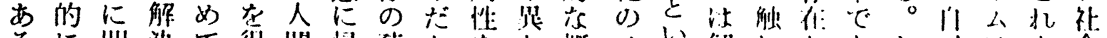

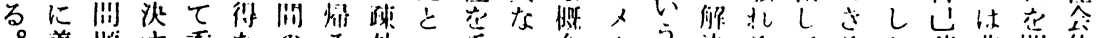

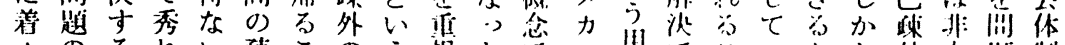

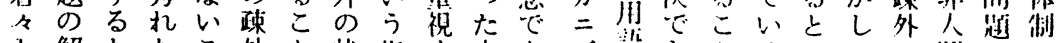

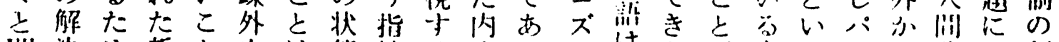

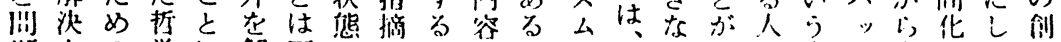

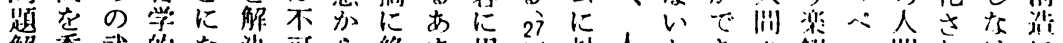

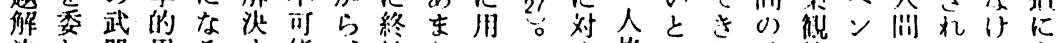

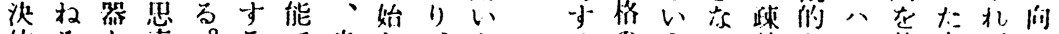

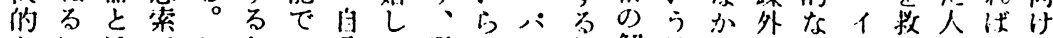

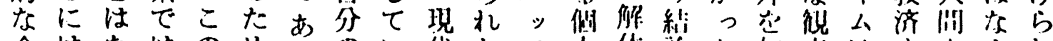

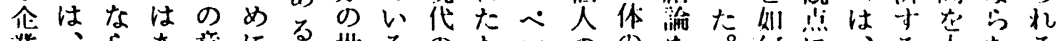

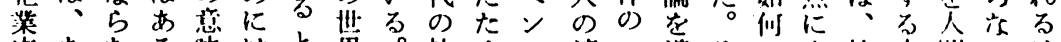

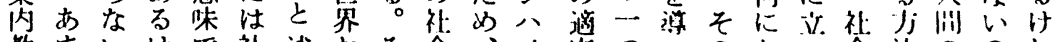

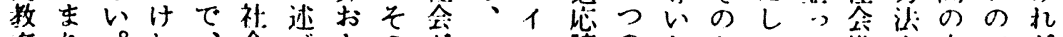

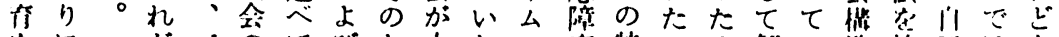

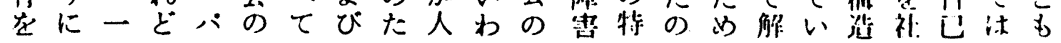


络いが

觉こ学企

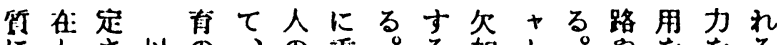

者と校莱 にしさ以の、の侸。る如

はを教が

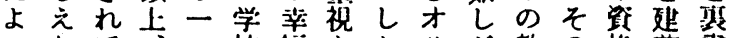

從亦青階

落㖫亡原

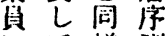

にて 样列

と

$\because$ ¿

(六)

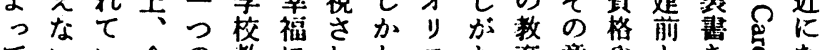

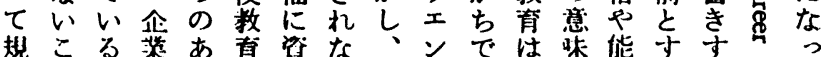

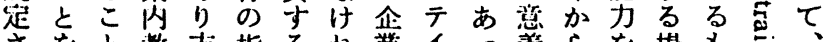

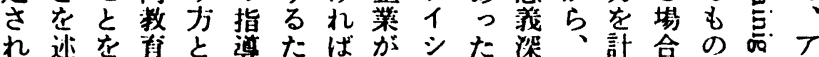

数ま1た

南たク集

倠 工阴

で|ii门ンで

あ山!: スあ

るによを

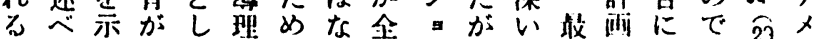

と企大

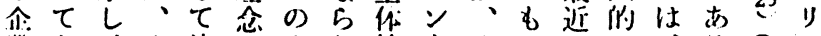

盌き、企波に企な社も企のにに、るの力

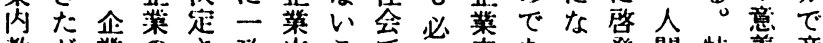

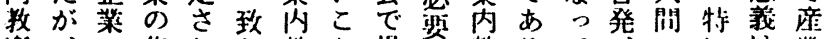

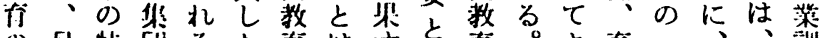

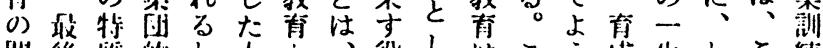

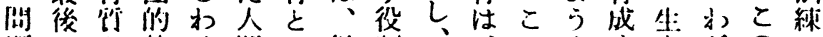

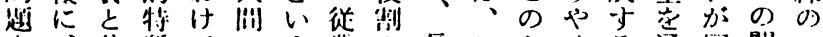
阔籍口心

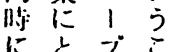
に学京 䋧厂を梳

行 证

清装布企

门なけ業

体:沵内

方: 上汶敃

被 站话

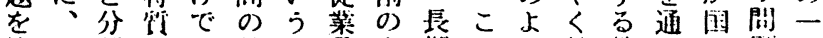

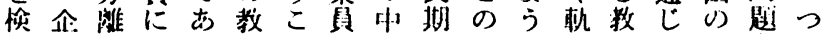

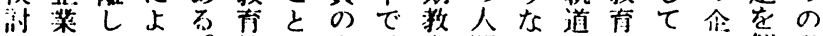

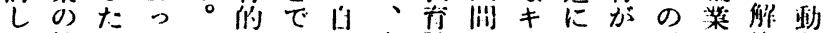
た躬企て形古已防計

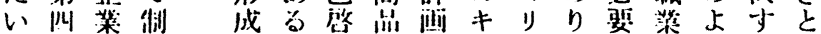

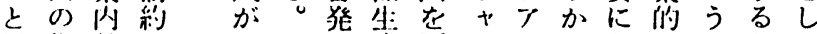
卧焦教さ企しと敢要りのけななにたて

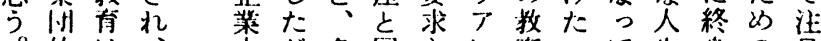
肉が冬闹さに苚して生身の目

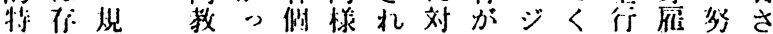

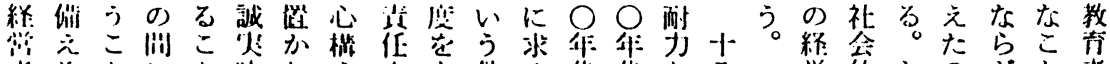

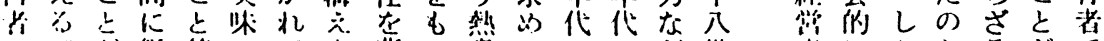

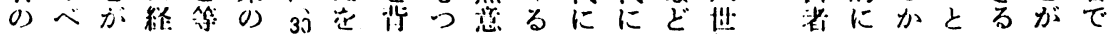

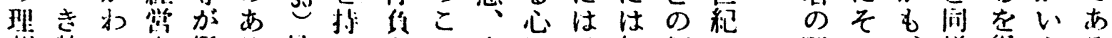

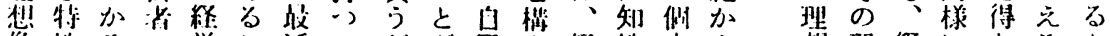

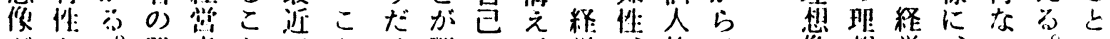

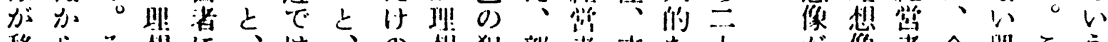

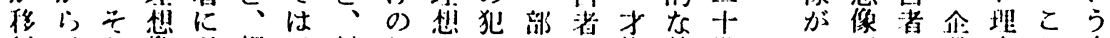

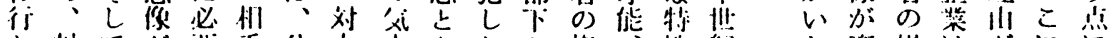

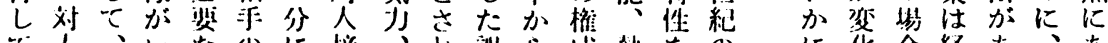

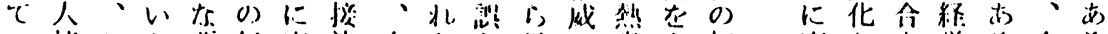

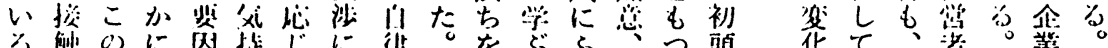

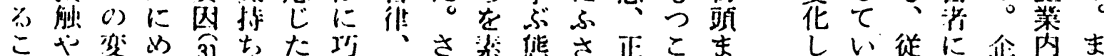

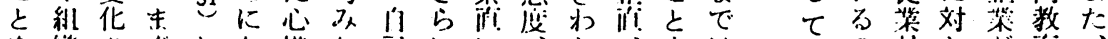

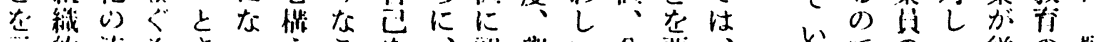

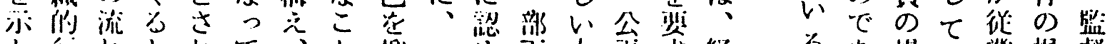

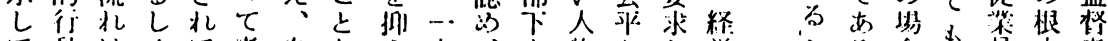

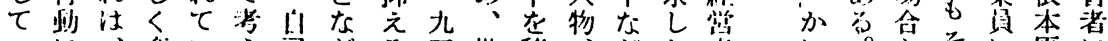

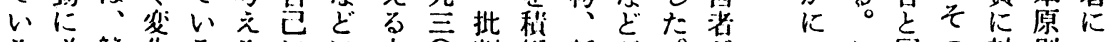

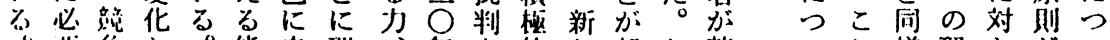

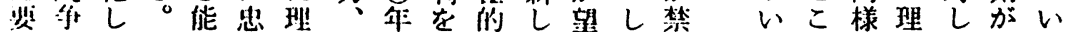

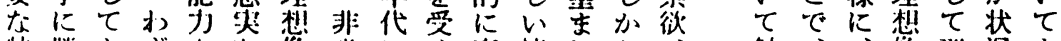

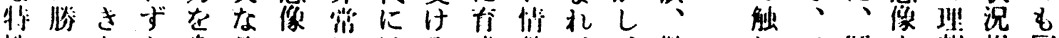

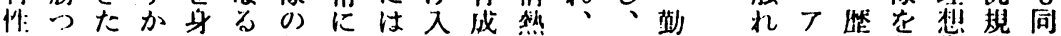

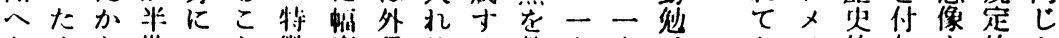

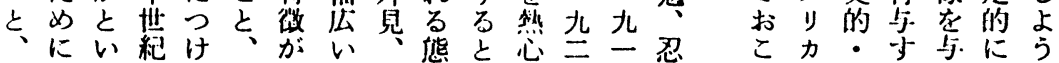




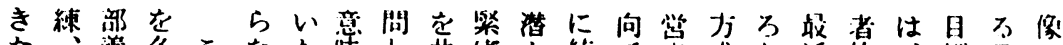

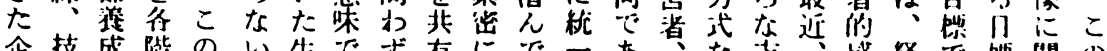

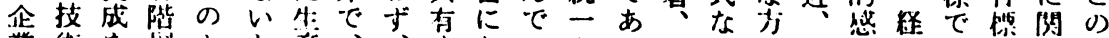

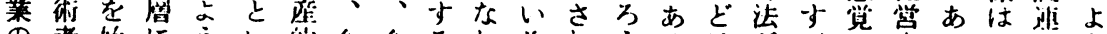

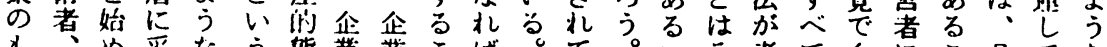

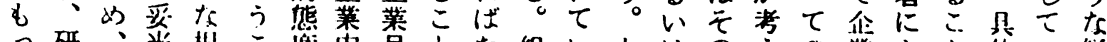

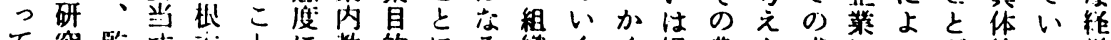

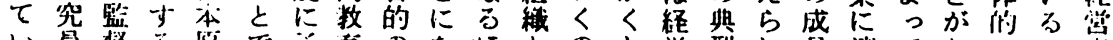

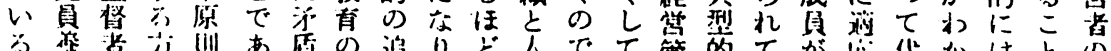

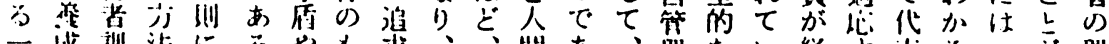

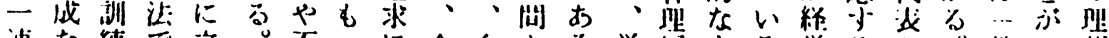

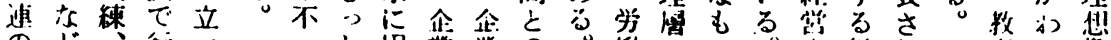

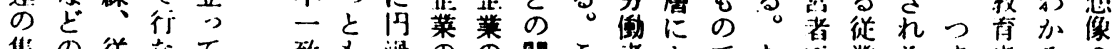

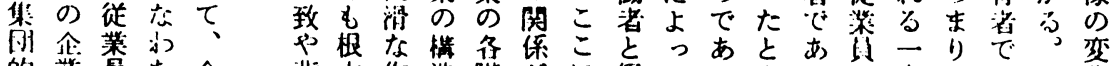

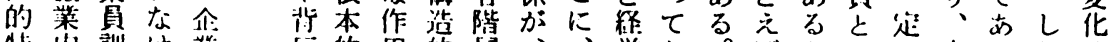

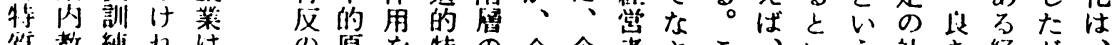

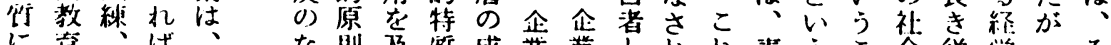

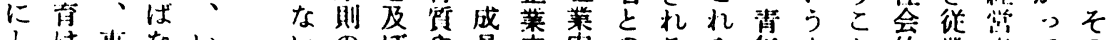

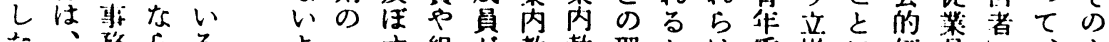

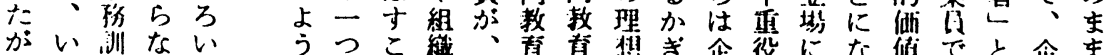

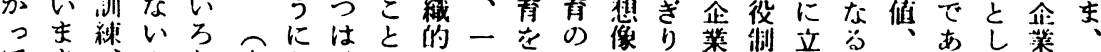

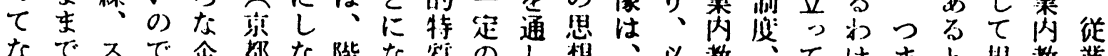

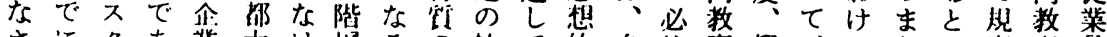

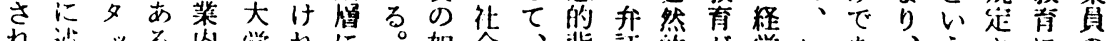

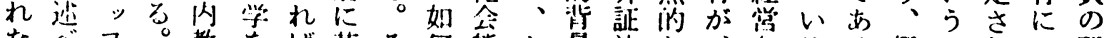

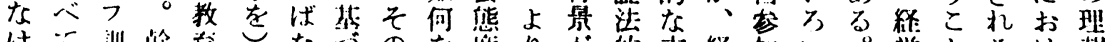

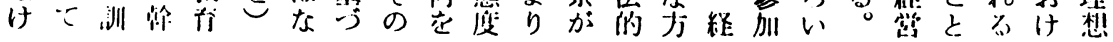

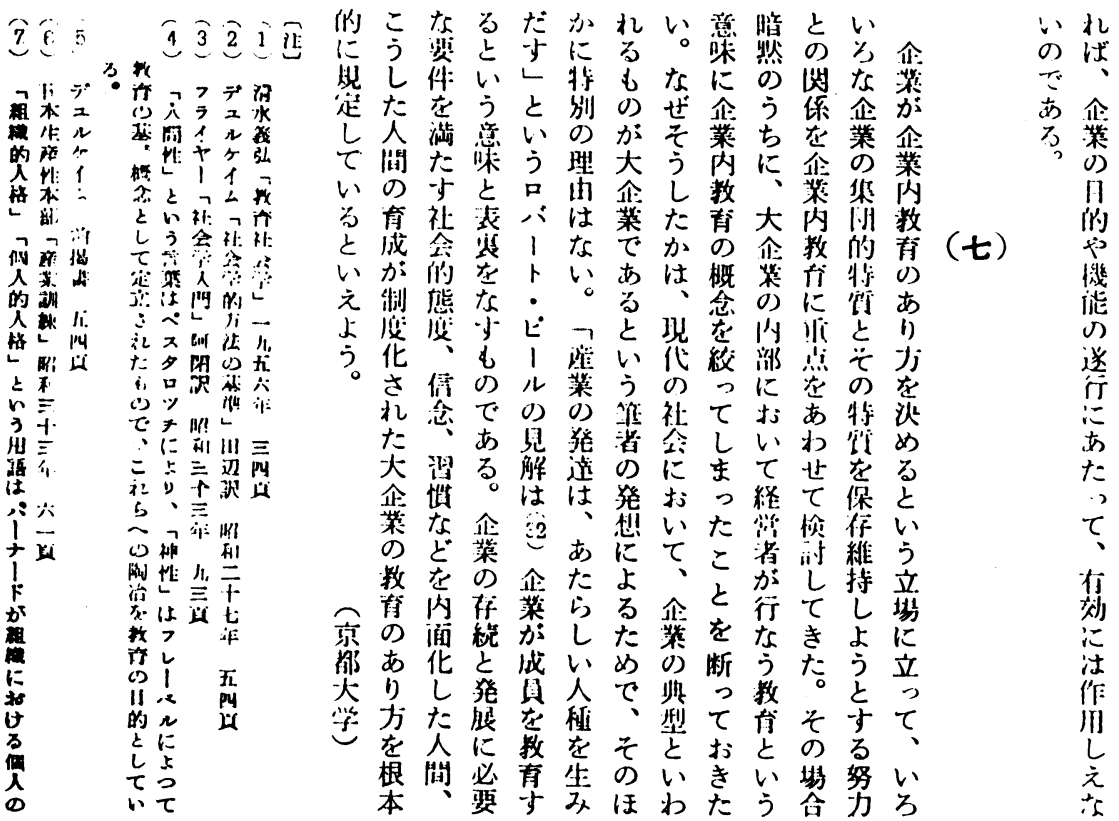




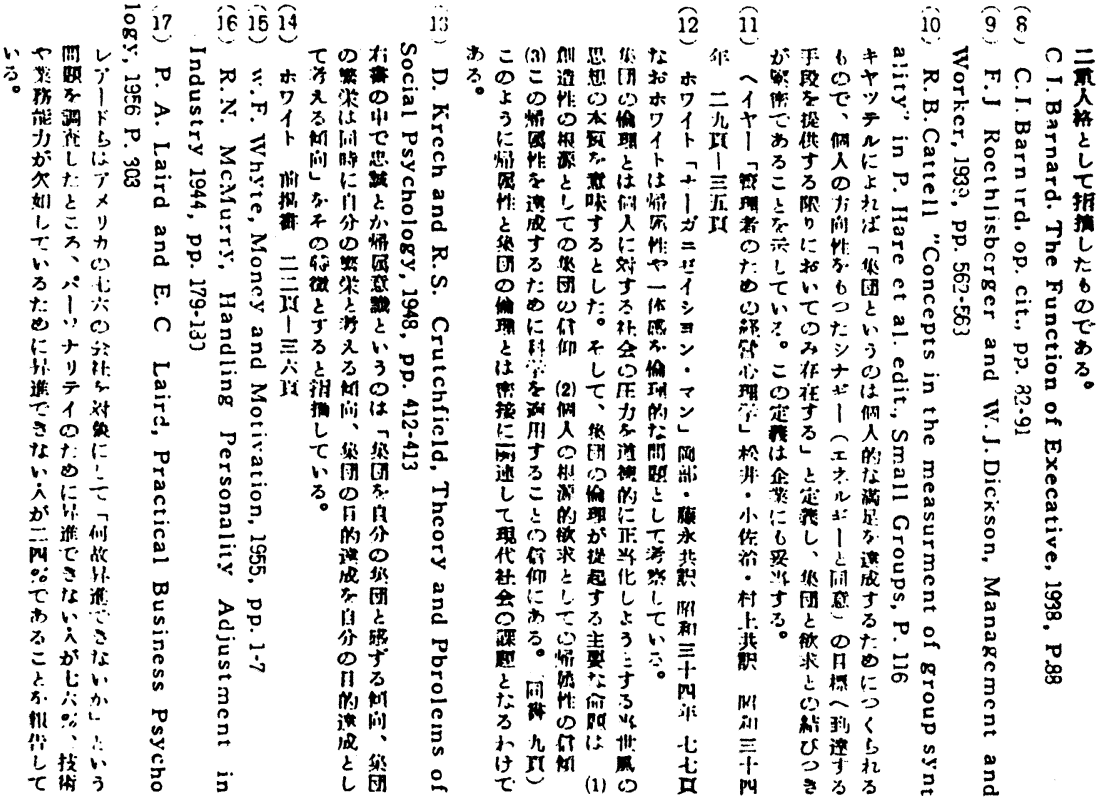

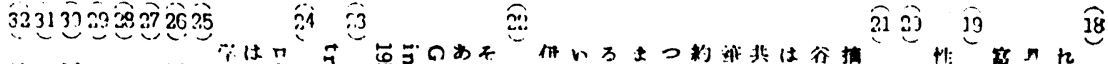

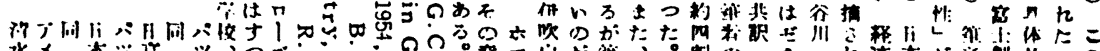

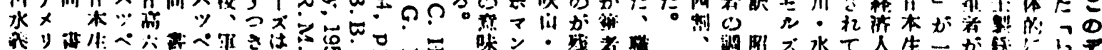

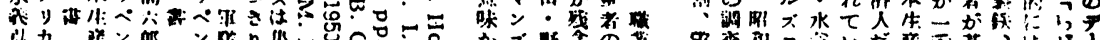

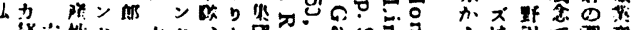

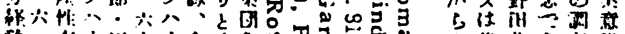

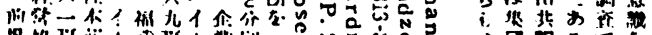
伤故

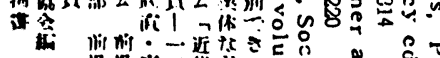

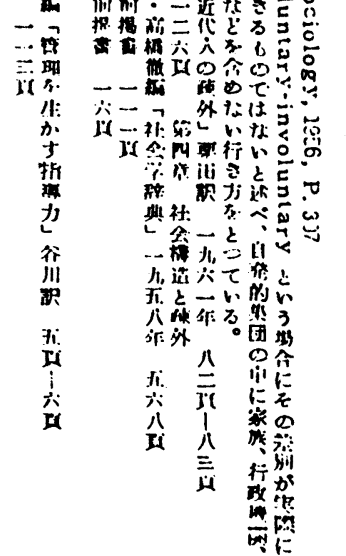

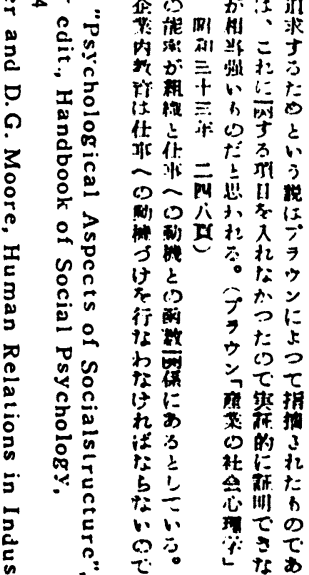

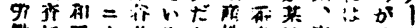

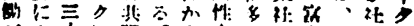

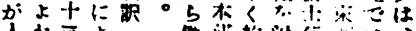

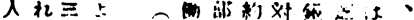

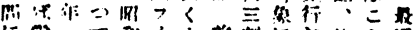

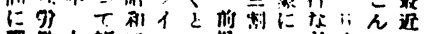

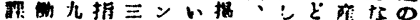

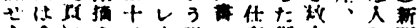

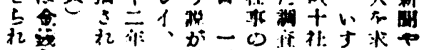

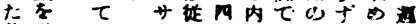

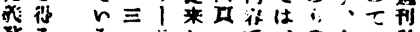

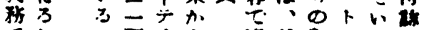

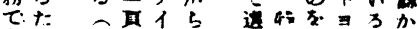

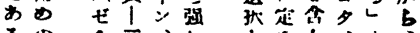

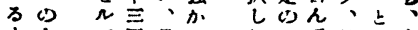

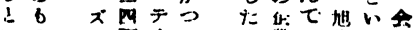
WO = II 1 t

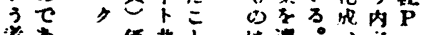

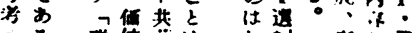

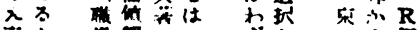

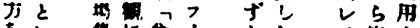

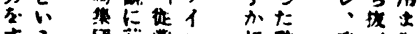

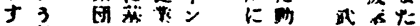

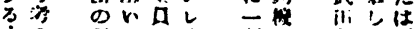

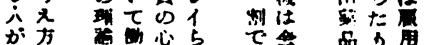

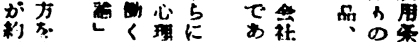

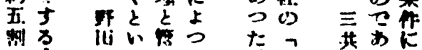

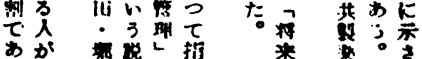


education." In Cermany Frofessor F. Edding (Director of the Hochschule für Internationale Pädagogische Forschung) has studied the macro-economic backgrounds of educational expenditures and found out some tendencies in their developments in modern countries. On the basis of these findings he tried to work out an analysing and forecasting method of educational expenditures of countries. By using this method, he tried to forecast the total educational expenditure of West-Germany in 1970, and explored the possibility of financing it on the basis of the possible economic growth of West-Germany by 1970 .

In October 1961 OECD held a conference in Washington on the "Economic Growth and Investment in Education." Profs. Svennilson, Edding ard Elvin wrote a report of this conference, in which we can find that Prof. Fdding has improved his forecasting method of educational expenditure and that many more economic aspects of educational developments have been elucidated. This analysing and forecasting method of educational expenditure is very useful in studying va:ious cases in educational finance in our country.

According to Prof. Edding, there is a close correlation between national income and educational expenditure (0.992 in 195.4), but Japan and the Soviet Union are exceptions to this close correlation. They show much higher ratios of investment in education than expected by their economic levels. He says that, in these countries, there is a strong will to improve the position of the country within a slort sran of time. This interpretation is very interesting and instructive in evaluating the progress of modernization of our country. We can learn from these studies not only a method of a long-range educational planning but also clues to historical review.

\section{Some Principles of Education in Enterprise}

\section{Yoshio Okada}

\section{(Kyoto University)}

The purpose of the report is to determine the extent to which sociological characteristics of modern enterprise effect the patterns of worker training and or of education for the employees.

I think that the contents or the purposes of education is enterprise are inevitably prescribed by formal organization and technical orgnization in industry. Therefore, education can not exist without considering social aspects of the group. In consequence, it is adequate 
to say that enterprise educates employees. There follows from this frame of reference education for the most desirable worker and how to train the employees.

In a word, an instruction to be promanagement-minded; an orientation to develop group identification and morale; a training to work hard and efficiently; an education to become a better citizen - these are required. These are closely related to the next four characteristics of the enterprise.

First, enterprise is an economic asscciation which pursues a profit. Secondly, enterprise is an organization which employees enter in order to satisfy their economical and occurational needs. Thirdly, enterprise is an agency between family and mass society. Lastly, enterprise consists of subgroups, such as, managers, professional workers, operators, office workers, etc.,

I pursue correlations between these specialities of industry and edncational plans in a concrete form.

\section{Technical Innovation and Education-in-Industry}

\section{Shōho Yamazaki \\ (Kunitachi Music College)}

This paper has three premises. In the first place, it requires a special method and approach in order to attack the question of cducation-in-industry, because enterprise is a symbolic, systematic group which constitutes the present society, and the problems in it decidedly effect the politics, economics and education of the society throughout present and future. Ascordingly, educational problems in industry remain not only to the interior aspect of the industry, but also relate to the whole aspect of educational system in society to a grealt extent. In the second place, the subjects of education-in-industry must be contsructively analyzed as a part of the total ecucational phenomenon in society. Lastly, at the same time education-in-industry must be viewed from the historical standpoint, otherwise significant implications of education-in-industry relating to technical innovation would not be grasped correctly.

Now in this paper, in Chapter I is explained historically how postwar education-in-industry has been organized for a managerial grcup as a mcdern attempt in enterprise. In the following chapter is described how organizations of labor forces and personnel management have been transformed with the progress of technical development since 1955 and how inevitably training for craftmanship has been 